Abstracta Iranica

Revue bibliographique pour le domaine irano-aryen

Volume 37-38-39 | 2018

Comptes rendus des publications de 2014-2016

\title{
Omid Azadibougar. The Persian Novel: Ideology, Fiction and Form in the Periphery
}

\section{Laetitia Nanquette}

\section{Q OpenEdition \\ 1 Journals}

\author{
Electronic version \\ URL: http://journals.openedition.org/abstractairanica/46059 \\ DOI: 10.4000/abstractairanica.46059 \\ ISBN: 1961-960X \\ ISSN: 1961-960X \\ Publisher: \\ CNRS (UMR 7528 Mondes iraniens et indiens), Éditions de l'IFRI
}

Electronic reference

Laetitia Nanquette, « Omid Azadibougar. The Persian Novel: Ideology, Fiction and Form in the Periphery », Abstracta Iranica [Online], Volume 37-38-39 | 2018, document 6, Online since 30 December 2018, connection on 26 September 2020. URL : http://journals.openedition.org/abstractairanica/46059 : DOI : https://doi.org/10.4000/abstractairanica.46059

This text was automatically generated on 26 September 2020

Tous droits réservés 


\title{
Omid Azadibougar. The Persian Novel: Ideology, Fiction and Form in the Periphery
}

\author{
Laetitia Nanquette
}

\section{REFERENCES}

Omid Azadibougar. The Persian Novel: Ideology, Fiction and Form in the Periphery. Leiden:

Brill, 2014, $x+240$ p. (Textxet: Studies in Comparative Literature, 76)

1 This book brings an innovative perspective to the debates on the novel in modern and contemporary Persian literature by formulating clear questions, without getting into nationalistic arguments or vague evaluative judgements. The book aims to give a systematic and independent literary critical approach to modern and contemporary Persian literature and it masterfully reaches its goal. It brings much clarity to our understanding of the novelistic in the Persian literary system, the literary discourse in Iran, as well as the role of modern Persian literature globally. The first chapters discuss the genre of the novel along with ideas of ideology, form, and imitation. Later chapters challenge previous analyses of well-known novels such as Hedayat's The Blind Owl, Parsipur's Women without Men and Pirzad's I Will Put Out the Lights by offering a detailed and convincing textual reading based on the principles developed in the first chapters. This study is an essential resource for scholars working on modern Persian literature. 


\section{AUTHORS}

\section{LAETITIA NANQUETTE}

University of New South Wales, Sydney 